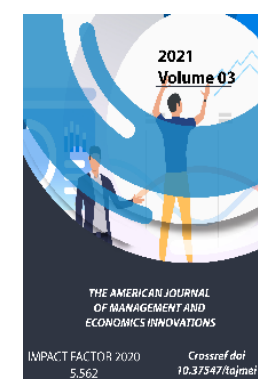

\title{
Project Finance - An Important Factor Of Economic Modernization
}

\author{
Zoyirov L.S. \\ Candidate Of Economical Sciences, Associate Professor, Tashkent Institute Of Finance, \\ Uzbekistan
}

Journal Website:

http://theamericanjour

nals.com/index.php/taj

mei

Copyright: Original

content from this work

may be used under the

terms of the creative

commons attributes

4.0 licence.

\section{ABSTRACT}

The article reveals the essence, content, features of project financing and its role in the modernization of the economy. The main participants of project financing and their functions, types of project financing are described. The foreign experience of organizing and implementing project financing in priority sectors of the economy is investigated. Based on the results of the study, conclusions were drawn about project financing and recommendations were developed on the development of this sphere.

\section{KEYWORDS}

Modernization, investments, investment projects, project financing, cash flow, investment loans, risk, commercial banks, feasibility study.

\section{INTRODUCTION}

Project financing logically means investment lending, and the financial source of debt service in financing investment projects is the net cash flows from the project. At the same time, project financing represents a special form of raising funds for the financing of large investment projects. This means that project financing contributes to the successful implementation of large industrial projects by attracting investment. This will be achieved through the implementation of an effective investment policy of the state. As the President of the Republic of Uzbekistan noted, "World experience shows that a country that pursues an active investment policy has achieved sustainable growth of its 
economy. That is why it is no exaggeration to say that investment is the driver of the economy, in Uzbek, the heart of the economy" [1, p. 120]. At the same time, investment also envisages the construction of large industrial facilities as a driver of the economy. In particular, project financing involves the financing of large costs associated with the construction of large facilities, in which investment resources are combined and mobilized to finance a major investment project.

Project financing involves financing large investment projects and programs aimed at attracting advanced technologies to the country, modernization and technical reequipment of enterprises on the basis of modern equipment, production of high quality consumer goods, expanding the country's export potential, services to foreign economic activity.

In recent years, due to the urgency of the role of project financing in the development of the economy, the development of its priority sectors, the legal and institutional framework for the development of project financing in our country is being improved. Commercial banks are actively involved in the implementation of investment programs through the widespread implementation of syndicated loans in accordance with international banking standards, including through the attraction of foreign bank capital. Of course, such measures require an in-depth study of the nature and practice of project financing.

\section{LITERATURE REVIEW}

Theoretical and methodological bases, peculiarities of project financing, its role in financing investment projects have been studied in the scientific works of foreign scientists - E. Yeskomb, D. Morozov, M. Fedotova, I. Nikonova, N. Lysova. In particular, in E. Yescomb's research, project financing is an important form of investment attraction; The use of such financing in construction, energy, oil and gas, mining, as well as in the construction of large infrastructure facilities is widely covered [2, p. 21]. In D. Morozov's research, project financing is a project lending in various forms, based on the fact that the source of loan repayment is provided by the project revenues [3, p. 144]. In the scientific works of M. Fedotova, I. Nikonova, N. Lysova [4, p. 73] the content, principles, features of project analyses, which forms the basis of project financing, are analyzed. The history of the formation of project financing, its problems and directions of development are revealed.

\section{THE MAIN FINDINGS AND RESULTS}

In the research of D. Gozibekov, an economist who has conducted research in the field of project financing in our country, project financing with its complex financial relations (syndicated credit or multi-stakeholder participation in lending) provides material guarantees to the creditor; radically different from the financing of projects with the implementation of financing on the basis of long-term contracts for the purchase of products produced in exchange for projects, products financed by the project at predetermined prices (subject to changes); issues such as the distribution of risks of debt repayment among participants and the purchase with a significant reduction, and the fact that such contracts become a reliable 
supply of debt [5, p. 600]. The textbook of B.Mamatov, D.Khojamkulov, O.Nurbekov on the subject studies the peculiarities of project financing and foreign experience [6, p. 391]. However, the issue of project financing in our country has not been studied in detail.

Project financing is one of the most advanced modern forms of financing. So what is the content of project financing and how can it be described? There are different opinions on this issue. For example, according to Deutsche Bank (Germany): "Project financing is the financing of the purchase, organization or construction of fixed assets under a project, in which the lender focuses mainly on: [7, pp. 2033]

- Net cash flow received as a result of project implementation as a source of loan repayment (return rate);

- The source that ensures the safe repayment of the loan to finance the project, i.e. the client's ability - collateral, guarantees and other security.

Project financing is a type of lending for investment projects, in which the lender partially or completely bears the risks associated with the implementation of the project. If in ordinary credit operations of banks, the main emphasis is placed on the study of the creditworthiness of the borrower, the assessment of its financial and economic condition, as well as the property used as collateral, project financing will focus on project analysis. The object of the project analysis is the project documentation, i.e. the feasibility study of the investment project, and it has its own purpose, such as determining the financial and economic efficiency of the project, project costs, funding sources and risk assessment.

Project financing is the process by which a bank issues, evaluates and monitors loans, including the construction, renovation or technical re-equipment of credit production and service facilities, including the purchase of equipment or the establishment of fixed assets, and represents activities aimed at acquiring working capital.

The main difference between project financing and other types of financing is that the source of loan repayment is the income (profit) received as a result of the project. In commercial or investment loans, the source of loan repayment may also be the income received by the borrower from general activities. The additional income seen through the implementation of the project is the main source of loan repayment. If no additional income is generated through the implementation of the project or the economy is not achieved through the modernization of production under the project, such financing is not project financing and is a traditional financing based on a business plan.

Typically, project financing is a special type of lending by the bank, which is distinguished by the following features. First, the allocated loan is provided for the purchase of relatively large (large-scale) fixed assets (equipment, land, construction and installation work). Second, the project is calculated for an existing period, which has the power to be implemented separately from the project organizers when the need arises. Third, the fixed assets in the project or the proceeds from their use serve as collateral that the lender can withdraw in the event of nonpayment of interest on the loan. 
First of all, the basis of project financing is independent and clearly defined projects. The amount of net cash flows received as a result of the project should be determined in such a way that it is possible to take into account future contingencies. At the same time, the project must meet the needs and interests of a large number of project participants. The project should provide for the possibility of appropriate distribution of risks among its participants.

Given the high level of risk involved in project financing, lenders strive to ensure effective risk management.

Projects financed through project financing can participate mainly in the following sectors and sectors of the economy: telecommunications; transport; mining of minerals; energy; processing and some other industries.

Long-term bank loans of investment projects can be considered as a small form of project financing in some cases. This is due to the following factors:

- First, from the point of view of commercial banks, credit operations under project financing are high-risk operations. In the project financing system, the bank provides a loan to the borrower without the right of regression. The source of loan repayment and interest payment is the income from the implementation of the investment project. Commercial banks receive high interest as a reward for accepting risks. Thus the bank insures high risk;

- Secondly, the main focus of project financing is on risk assessment and mitigation in investment projects. At the same time, banks, with the involvement of consultants, assess the effectiveness of the investment project, the dynamics of cash flow, product sales prospects, project risks;

- Third, the participation of many participants in the implementation of the project is provided: the initiator of the project; project company; consultants; contractors; equipment suppliers; insurance companies and guarantor banks; creditors, etc. The presence of project companies in project financing is one of its main features. Project companies are organized by project sponsors in the context of project implementation. If in ordinary credit operations the bank is interested in the results of the borrower's previous financial performance, in the implementation of the investment project the bank focuses on assessing the financial and economic efficiency of the project and the guarantees of the project company. The loan is reflected not in the balance sheet of the founders, but in the balance sheet of the project company. This method is called "of balance sheet";

- Fourth, in project financing, the lender focuses on the control of the project implementation process, in many cases, if this function is performed by lenders, in some cases, special companies are invited for this purpose. The private company constantly monitors the implementation of the project on the basis of a contract with the debtor, the debtor, in turn, periodically reports to the company on the work done;

- Fifth, in the project financing market, 
banks can participate as performers of various functions: as a creditor bank; as a guarantor and financial advisor; as a leasing institute, etc.;

- Sixth, due to the high risk, the interest rate on the loan will be high, as well as the presence of excessive commission costs (commission fees for project evaluation, financing arrangements, monitoring); high pre-project costs; failure to consider a bank financing application without a fully developed pre-project documentation; strict control of the debtor's activity by the bank. Therefore, in many cases, the borrower finds it necessary to use a simple traditional form of investment financing.

The essence of project financing is targeted lending for the implementation of large investment projects in this non-regressive or limited regression of credit to the borrower, which is reflected in the calculation of funds accumulated during the investment activity as collateral for the borrower's payment obligations.

Based on the above, we show the specifics of project financing through Figure 1.

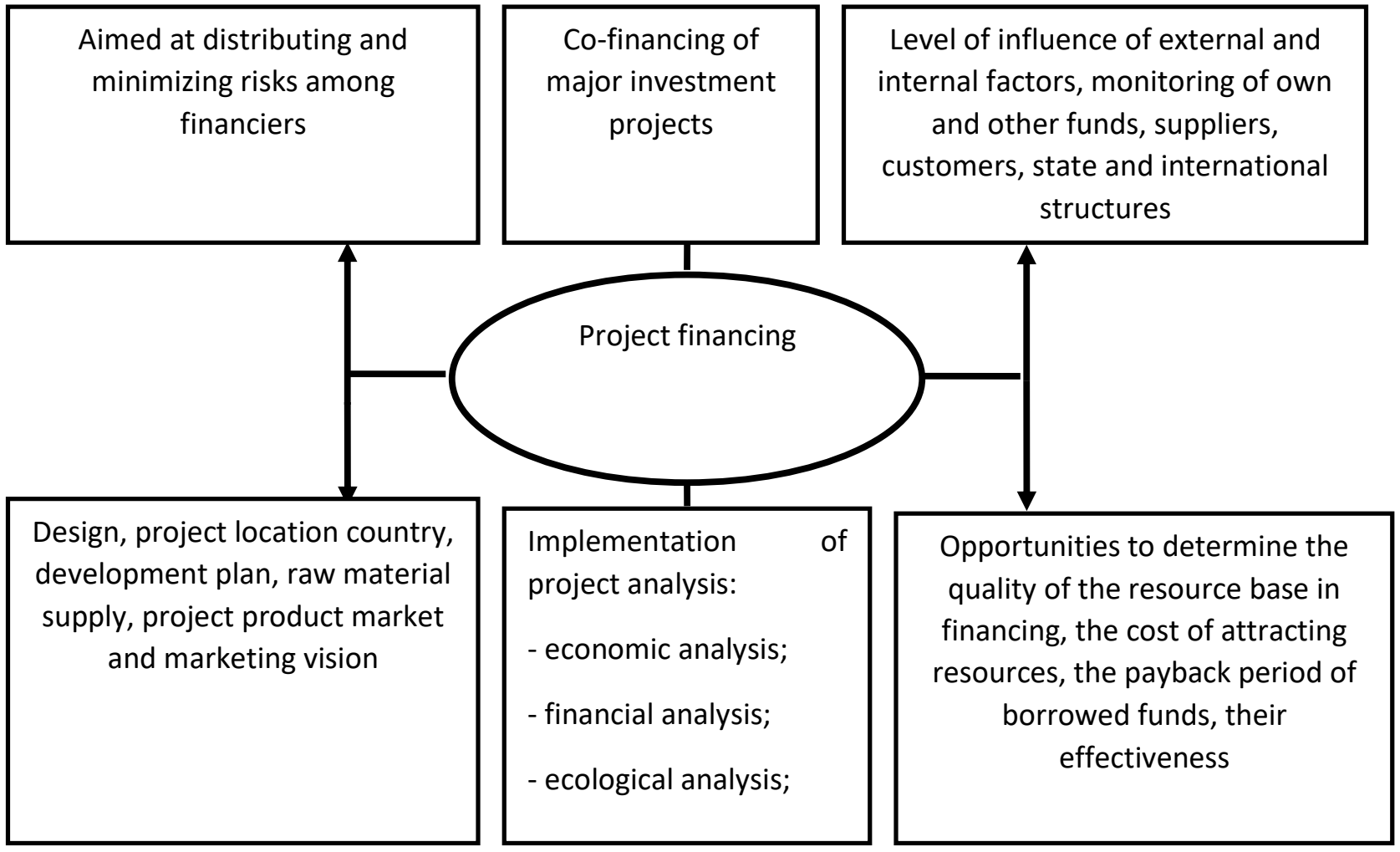

Figure 1. Peculiarities of project financing

It should be noted that the project financing involves the syndication of funds with the participation of funds from various investors and creditors. In this regard, we can also call project financing syndicated lending. The role of banking syndicates and consortiums in financing the projects currently operating in the "Eurocredit" market is growing day by day. For example, in 2016, the volume of project financing in Eastern European 
countries amounted to 24309.3 billion. USD, and the number of transactions in this regard reached 38 (Table 1). This is 10,816.2 billion more than in 2015. The Russian Federation is the leader in terms of the number of transactions, while Turkey is the leader in terms of the number of transactions. This shows that project financing is developing in Eastern European countries.

Table 1

Volume of project financing and number of transactions in Eastern European countries in 2015-2016 [8]

\begin{tabular}{|c|c|c|c|c|c|}
\hline \multirow{2}{*}{$\begin{array}{c}\text { Eustern } \\
\text { countries }\end{array}$} & $\begin{array}{c}\text { 2016 year } \\
\begin{array}{c}\text { The volume of } \\
\text { transactions, bln. } \\
\text { U.S. dollars }\end{array}\end{array}$ & $\begin{array}{c}\text { Number of } \\
\text { transactio } \\
\text { ns, pcs }\end{array}$ & $\begin{array}{c}\text { The volume of } \\
\text { transactions, bln. } \\
\text { U.S. dollars }\end{array}$ & $\begin{array}{c}\text { Number } \\
\text { of } \\
\text { transactio } \\
\text { ns, pcs }\end{array}$ & Change,\% \\
\hline $\begin{array}{c}\text { Russian } \\
\text { Federation }\end{array}$ & 19081,2 & 12 & 622,9 & 4 & 2963,3 \\
\hline Turkey & 3446,6 & 17 & 10194,5 & 13 & $-66,2$ \\
\hline Slovenia & 1077,8 & 1 & 123,1 & 1 & 775,5 \\
\hline Croatia & 284,6 & 1 & - & - & - \\
\hline Georgia & 177,0 & 2 & 250,0 & 1 & $-29,2$ \\
\hline Poland & 131,8 & 2 & 785,5 & 7 & $-83,2$ \\
\hline Macedonia & 69,0 & 1 & - & - & - \\
\hline Litva & 41,3 & 2 & 95,4 & 1 & $-56,7$ \\
\hline
\end{tabular}

Eurocredits and loans from other developed foreign banks, funds from foreign investors, and loans from joint-stock commercial and private banks are also becoming more active in financing investment projects in our country. Given Uzbekistan's limited domestic resources and relatively low external debt burden, the "investment thirst" that has accumulated over the years, as well as the need to address imbalances in the economy by addressing pressing economic challenges, developing private entrepreneurship and implementing infrastructure projects, have led to increased external debt. This, in turn, has led to an

increase in the activity of commercial banks to attract foreign credit lines and the development of the consumer credit market. As a result, the balance of credit investments in the economy increased by $50.9 \%$ to 208 
trillion soums. At the same time, the balance of loans in national currency increased by $48.7 \%$ (including loans to the population by $63.5 \%$ ), the balance of loans in foreign currency increased by $53.8 \%$ [9]. This situation is a positive development in terms of accelerating investment activities, implementation of major investment projects and the development of project financing.

\section{CONCLUSIONS AND SUGGESTIONS}

Based on the above, the following conclusions and recommendations on project financing can be formulated:

- The main type of project financing is syndicated lending, in which various investors and creditors participate at their own risk and expense;

- The object of project financing is projects that have a specific purpose, are planned to be economically and financially efficient;

- In project financing, risks are distributed among financiers and the main focus is on minimizing risks;

- The source of loan repayment in project financing is the income received as a result of the project, and project financing differs from other types of financing in terms of loan security;

- The main process in project financing is the technical, economic, financial, environmental analysis of project documents, the depth and level of which determines the future prospects of the project;

- It is necessary to create a regulatory framework for project financing based on the study of international best practices in project financing, including the development of the Regulation "On project financing";

- It is necessary to further intensify the inflow of foreign direct investment into the economy and increase the attractiveness of the investment climate. This will allow implementing large industrial facilities on the basis of project financing;

- It is necessary to reduce the devaluation of the national currency against foreign currencies and increase the efficiency of project financing by diversifying exports of manufactured products.

\section{REFERENCES}

1. Yescombe E.R. (2015) Principles of project financing. Per. from English Published with the assistance of the Eurasian Development Bank and Alt-Invest. Moscow. “Alpina-Publisher”. - p. 120. (Йескомб Э.Р. Принципы проектного финансирования. Пер. с англ. Издано при содействии Евразийского банка развития и “Альт-Инвест". - М.: “Альпина-Паблишер”, 2015. - 120 с.)

2. D.S. Morozov. Project finance: risk management and insurance. - Moscow. “Ankil”. 1999. - р. 21. (Морозов А.С. Проектное финансирование: управление рисками и страхование. М.: «Анкил», 1999. -С. 21.)

3. Fedotova M., Nikonova I., Lysova N. (2016) Project financing and analysis. Moscow: "Yurayt". - p. 144. (Федотова М., Никонова И., Лысова Н. Проектное финансирование и анализ.- М.: «Юрайт», 2016. - 144 с.)

4. Gozibekov D.G. (2003) Investment financing issues. - Tashkent: "Finance".p. 73. (G'ozibekov D.G'. Investitsiyalarni 
moliyalashtirish masalalari. - T.: «Moliya», 2003. - B. 73.)

5. Mamatov B.S., Khojamkulov D.Yu., Nurbekov O.Sh. (2014) Investment organization and financing. Textbook. Tashkent Financial Institute. - Tashkent: "ECONOMY-FINANCE". - p. 600. (Mamatov B.S., Xo'jamqulov D.Yu., Nurbekov O.Sh. Investitsiyalarni tashkil etish va moliyalashtirish. Darslik. Toshkent moliya instituti. - T.: "IQTISODMOLIYA", 2014. - 600 b.)

6. Behrens V., Havranek P.M. (1995) Guidelines for assessing the effectiveness of investments: Translated form English Moscow. AOZT "Interexpert", INFRA-M. - р. 391. (Беренс В., Хавранек П.М. Руководство по оценке эффективности инвестиций: Пер. с. англ. - М.: АОЗТ
«Интерэксперт», ИНФРА-М. 1995. - С. 391.)

7. Ezangina I.A. (2017) Strengthening the role of development institutions in the mechanism of bank project financing. Finance: theory and practice. - Tashkent. No 6. - pp. 20-33. (Езангина И.А. Усиление роли институтов развития в механизме банковского проектного финансирования // Финансы: теория и практика. 2017. Т. 21. № 6. С. 20-33.)

8. https://review.uz/ru/post/investitsiyajaraenlarini-jadallashtirishning-ikki-jixati.

9. http://cbu.uz/uzc/press-tsentr/pressrelizy/2020/01/182897/?utm_source=uznet .press\&utm_campaign=topic. 